\title{
THE AREA OF SUPPLY CHAIN QUALITY MANAGEMENT - THIRD PARTY LOGISTICS IN CASE STUDY
}

doi: 10.2478/cqpi-2019-0008

Date of submission of the article to the Editor: $06 / 05 / 2019$

Date of acceptance of the article by the Editor: 29/05/2019

Marta Kadłubek - orcid id: 0000-0002-0424-8316

Czestochowa University of Technology, Poland

Abstract: The area of quality management is sometimes dedicated to be included in the research into the supply chain in relation to the exploration of problems of the efficiency of the supply chain. In the subject literature, there are numerous indications taking into account complex relations in the supply chain and identifying quality aspects by maximizing the phenomenon of synergy in the supply chain.

In accordance with these implications, an attempt has been made to analyze the area of quality management in the area of the supply chain in the selected company, being the link of the supply chain. The obtained research results have been partially presented in this paper. The objective of the paper is to present the results of the research into selected areas of quality management of the supply chain in the company of the transport-forwarding-logistics industry.

The empirical research was conducted through the survey questionnaire the objective of which was to obtain the opinions on the key aspects of quality management of the supply chain. The recipients of the questionnaire were 263 employees of the international logistic operator with branches, among others, in the Silesian Voivodeship, Poland.

Keywords: quality management, supply chain management, efficiency

\section{INTRODUCTION}

The lack of the unified theory of quality causes that all the aspects leading to positive changes in the enterprise - increasing the level of quality of products and services as well as cooperation, can be considered as the components of quality assurance even seemingly very distant, such as the overall mission and goodwill or after-sales service. A similar observation applies to supply chain management and is expressed through the multiplicity and diversity of views relating both to the essence of the supply chain and the principles which its functioning is based on.

The integration of the concept of supply chain management and quality management constitutes a new research field, which is pinpointed by Sharma et al. (2012), claiming that, in the view of the research of the world literature, only about $8 \%$ of the analyses of the supply chain has related to its quality. At the same time, the existing significant achievements in the area of the theory and methodology of the aforementioned 
concepts are, most of all, associated with the narrow approach to the disciplines, both in axiological and epistemological terms (Hu et al., 2014). This is also confirmed in the light of critical analysis of national and international literature in the field of logistics, supply chain management and quality management. The cited research results lead to accepting the hypothesis that integration trends mostly include logistics and quality management (Czajkowska and Stasiak-Betlejewska, 2015; Kadłubek, 2018). This integrated or quasi integrated approach is noticeable in the views of the authors, among others, such as Biesok (2013), Detyna (2015), Frąś (2013), Kardas et al. (2011), Lin et al. (2013), Łunarski (2012).

As indicated, among others, by Robinson \& Malhotra (2005), quality management should be included in the research into the supply chain in relation to the exploration of problems of the efficiency of the supply chain. This research takes into account complex relations in the supply chain and identifies the strategies minimizing costs by maximizing the phenomenon of synergy in the supply chain. In turn, the research by Perona \& Miragliotta (2004) indicated that quality control (Ulewicz et al., 2018) shapes the results of links of the supply chain and contributes to an improvement in the overall performance of the enterprise.

In accordance with the above implications, an attempt has been made to analyze the area of quality management in the area of the supply chain in the selected company, being the link of the supply chain and the obtained research results have been partially presented in this paper. The objective of the paper is to present the results of the research into selected areas of quality management of the supply chain in the company of the transport-forwarding-logistics industry.

\section{METHODOLOGY OF THE RESEARCH}

The empirical research was conducted through the survey questionnaire the objective of which was to obtain the opinions on the key aspects of quality management of the supply chain. The recipients of the questionnaire were the employees of the international logistic operator with branches, among others, in the Silesian Voivodeship, Poland. The questionnaire was carried out in the road transport division and was addressed to a wide audience - from the employees hired in the section of warehouse operations, through the employees in the national section, to the ones dealing with international transport. The research was conducted in June 2018 online via the internal platform operating in the company and the respondents gave answers during working hours when they had access to the platform.

In order to facilitate the respondents to express opinions on the issues where there was no clear answer, the decision was made to use the 5-point Likert scale in the case of some of the questions. Due to the survey-like nature of the research, the analysis of the results and the conclusions were based on the analysis of the frequency of the responses given.

\section{RESULTS}

263 people participated in the research. A vast majority of those questioned, amounting to $70 \%$ of all the respondents, had higher education of bachelor of engineering, BA and MA.

The respondents were to specify the place in organizational culture relating to the section of the organization in which they worked. In the road transport section, being the object of the research, there are three sections: warehouse operations, national 
transport and international transport. Most of the respondents, since 52\%, were the people employed in the section of international transport, $29 \%$ of the respondents came from the section of warehouse operations whereas $19 \%$ from the section of national transport

The employees taking part in the research were also to specify what position they occupied. Due to the specificity of the surveyed company and a wide range of the positions occupied, the employees had to qualify their position in the organization to one of five groups of posts. The following responses were obtained: $73 \%$ of the respondents occupied the position of an assistant or a specialist (an assistant - 87 people, a specialist - 104), $20 \%$ of those questioned specified their post as an entrylevel position and the other $7 \%$ was included in the management staff - managing directors, leaders and managers.

In terms of the years of service, $53 \%$ of the respondents worked for the company for less than 5 years. The second largest group of workers were the people working for over 20 years- $12 \%$ of the respondents. The smallest group of the respondents were the employees with the seniority of 6 to 10 years.

First of all, the respondents were asked about the knowledge of quality assurance systems being implemented in the company. The research indicated that $46 \%$ of those questioned had no knowledge of the quality assurance systems possessed by the company. The other group of the respondents $-54 \%$ gave the answers confirming the knowledge of quality assurance systems. The question was open and the respondents could give more than one answer concerning the utilized quality assurance systems. The largest group of the respondents amounting to $92 \%$ of those among the ones with the knowledge of quality assurance systems indicated internal guidelines for quality assurance systems, which are gradually implemented by the Department of Risk Management and Quality. The second position among the responses given ( $86 \%$ of the employees) was occupied by: internal regulations concerning the quality policy issued by the Board and the President (common ethical principles on the issues of anti-corruption, protection of competition, protection of human rights and rights of workers and care for the environment, ethics and the rule of law). Subsequently, the respondents listed the possessed award of Bronze logistics operator of the year $-72 \%$ of the respondents' indications, ISO 9001 and 14001 standards $-61 \%$, the participation in the program of Rzetelna Firma (Reliable Company) $-33 \%$, CSR $-24 \%$ and the constant monitoring of KPI associated with quality, including customer satisfaction, level of complaints, number of new customers, increase in turnover in a group of existing customers - 18\%.

Another question related to the knowledge of safety assurance systems in the surveyed company. The obtained responses indicate that $31 \%$ of the respondents had no knowledge of the implemented safety assurance systems. The other respondents $(69 \%)$ gave the answers that there were the following safety assurance systems in the company:

- OHS system - $93 \%$ of indications,

- digital data anti-theft systems (IT area) - $68 \%$ of indications,

- personal data protection systems - $62 \%$ of indications,

- object protection systems - 39\% of indications,

- internal systems related to the transfer of extremely sensitive and confidential data $-25 \%$ of indications. 
The third question referred to the employees' knowledge of the key values organizational competences and standards which the implemented business strategy of the company is based on. The respondents, in $99 \%$ of the responses, showed the knowledge of the values and principles constituting the philosophy of the operation of the organization. Among the answers given by the respondents there were the statements such as:

- "the customer is the most important": we provide the highest quality, we are proactive and we make that doing business with us is easy - $99 \%$ of the respondents' indications,

- "the best results": we operate transparently and we are oriented towards the result, we work globally following the principle that we are the unity in spite of geographical borders. The basis of our operations is entrepreneurship and activities compliant with the global and local legislation - $98 \%$ of the respondents' indications,

- "genuine cooperation": we take the initiative, we communicate with customers with respect, we practice an open dialogue - $98 \%$ of the respondents' indications.

Another question related to the knowledge of the respondents of instruments of quality management used in the surveyed company. Among the respondents, $56 \%$ gave the answer that they did not know what methods, tools and techniques in the area of quality management were used for solving problems in the company. The other ones $-44 \%$ of the respondents listed in the following order:

- internal standards and regulations concerning quality - $90 \%$ of indications,

- Key Performance Indicators - $76 \%$ of indications,

- reports $-64 \%$ of indications,

- feedbacks - $34 \%$ of indications,

- periodic (internal and external) audits - $23 \%$ of indications.

In the fifth question, the respondents were asked to answer the question: "Does the process map in the Quality Manual correspond with the process map of the supply chain?". The responses given in as much as $31 \%$ indicated no awareness of the respondents relating to the existence of the Quality Manual and nearly 30\% of the respondents admitted having no knowledge. At the same time, $24 \%$ of those questioned confirmed the correspondence of the processes of both areas. The distribution of the responses to this question is presented in Figure 1.

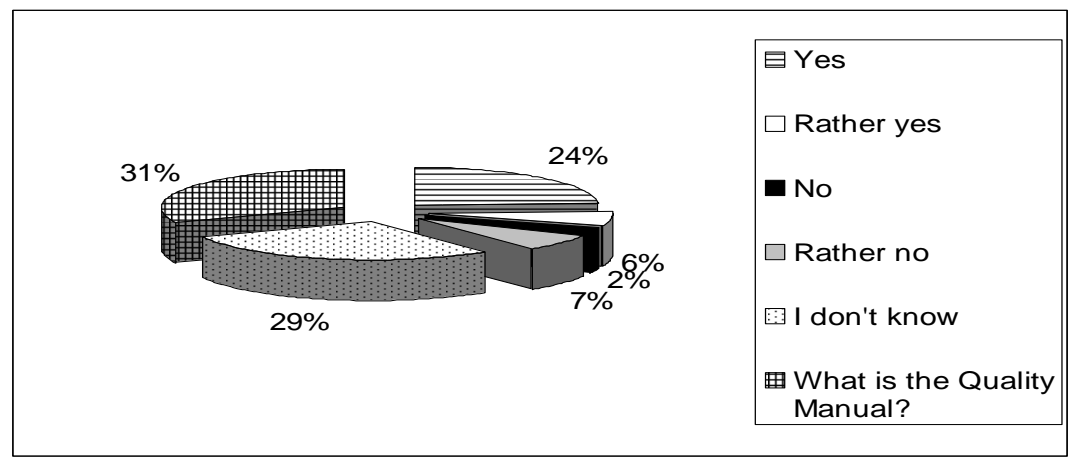

Fig. 1. Does the process map in the Quality Manual correspond with the process map of the supply chain? 
The objective of the questions included in this research area was to assess the knowledge of the respondents on the practices of supply chain management applied in the company. In the first question, the respondents were asked to answer the question concerning instruments of supply chain management utilized in the company. Among the respondents, $26 \%$ claimed that they did not know what instruments were applied in the area of supply chain management. The other group of the respondents (74\%) indicated different instruments while subsequently listing:

- Transportation Management System - 47\% of the respondents' indications,

- the applications, such as consignment tracking system, applications supporting the work of sales department - 39\% of the respondents' indications,

- Warehouse Management System - 36\% of the respondents' indications,

- the software allowing all the employees to work on the same set of data - $21 \%$ of the respondents' indications,

- platforms for customers and business partners enabling fast communication with experts $-18 \%$ of the respondents' indications,

- mission and logistics strategy - $6 \%$ of the respondents' indications.

In the second question, the respondents were asked to specify the role which the company played in the supply chain. The responses indicate that the majority of those questioned believe that the company has a strong market position (37\%). The full distribution of the responses is presented below:

- I don't know (2\%),

- It is hard to define (6\%),

- We are in a weak position (13\%),

- We are in a moderate position (23\%),

- We have a strong position (37\%),

- We are the leader (19\%).

The third question related to the identification of the type of the existing architecture of the supply chain, which is significant from the point of view of both the quality of relations in the supply chain and the assessment of quality of the supply chain. The distribution of the answers obtained from the respondents is the following:

- simple, uncomplicated (12\%),

- closed, concentrated on the inside of the organization (21\%),

- complex and hierarchical (36\%),

- networking (31\%).

In the fourth question, the respondents were asked about the knowledge of the process map in the company and interdependencies occurring between the processes. The obtained responses indicate that it is not possible to synthetically relate to this issue. On account of the global nature of the corporation in which the research was conducted, the process map is particularly complex and complicated. It can be assumed that the processes are complementary to each other. Some processes are utilized by all the users (respondents) whereas others are designed only for dedicated people.

The principal objective of the questions addressed to the respondents in the last third part of the research was to determine the impact of quality management and supply chain management on the efficiency of supply management, noticeable by the respondents. The first question related to the identification of the impact of the quality assurance system on the performance of the company. The largest proportion of the 
respondents $(60 \%)$ stated that the activities associated with quality assurance slightly and moderately affect the performance of the company. The distribution of the responses is shown in Figure 2.

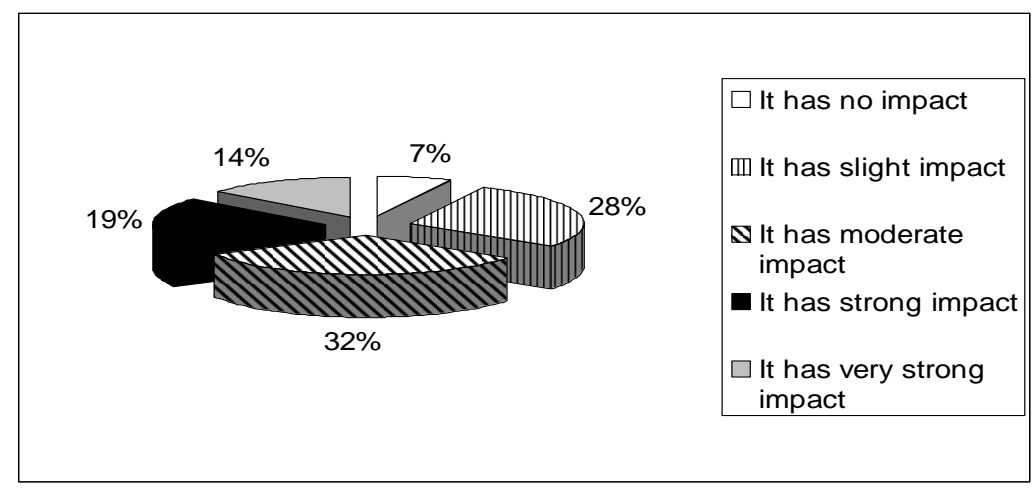

Fig. 2. To what extent does the possessed quality assurance system affect the performance of the company?

The second question related to the identification of the impact of the use of instruments of quality management on the performance of the company. In response to this question most of the respondents stated that instruments of quality management have very strong ( $41 \%$ of the respondents' indications) or strong $(27 \%$ of the respondents' indications) impact on the performance of the company.

Another question concerned the identification of the impact of the use of instruments of supply chain management on the performance of the company. The majority of the respondents $(73 \%)$ claimed that instruments of supply chain management have moderate impact on the performance of the surveyed company and only $5 \%$ of the respondents did not see this impact.

The fourth question related to the impact of changes in the environment of the supply chain, the link of which is the surveyed company, on the quality of relations with all groups of stakeholders and particularly customers who are mostly the purchasers of logistic services. The respondents stated that this impact is moderate (31\%) and strong (27\%). The distribution of the responses to the fifth question concerning the impact of changes in the environment on the quality of the supply chain was similar to the fourth question (Figure 3).

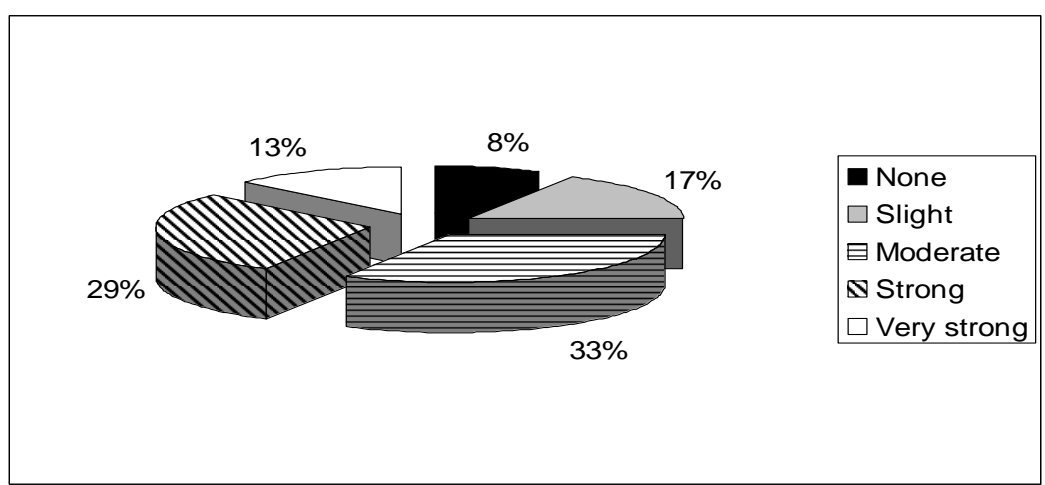

Fig. 3. What is the impact of changes in the environment on the quality of the supply chain? 
The last sixth question related to the ways of measurement of the performance as well as economic, social and process aspects being taken into account in the assessment of the efficiency of supply chain management. The responses focused around three groups of answers:

- KPI (the wider range of meters), among others, including measures and economic indicators, logistic ones and the ones associated with the quality of process implementation - $61 \%$ of the respondents' indications,

- EBIT (earnings before deducting interest and taxes) and financial liquidity $32 \%$ of the respondents' indications,

- Turnover - $14 \%$ of the respondents' indications.

\section{CONCLUSIONS}

In accordance with the indications of the literature, the conducted research into quality management of the supply chain should focus on the multifaceted analysis of factors affecting the performance of the company, moving from traditional quality control to quality management of the supply chain. In this fragmentary approach to the obtained results, the direction of the considerations, shifted to the empirical research, ought to move eventually towards the verification whether quality management of the supply chain improves the performance of the company and provides the higher efficiency of the supply chain. The main research field was to determine the impact of quality management of the supply chain on the results arising from cooperation in the supply chain. At the same time, the conducted research works focused on the issue of the role of only one link in the assessment of the efficiency of the supply chain.

The methodological approach adopted in the research, most of all, included the orientation towards the assessment of the employees of only one link of the supply chain in relation to quality management and its impact on the results of the supply chain. It should be noted that it is important to determine the position in the supply chain and the implemented business practices. Moreover, although the whole study underlines the significance of the efficiency of customers and suppliers for the entire supply chain, the presented fragments of the research relating to the specific aspects influencing the performance of the enterprise are general considerations in their nature thus only outlining the epistemological framework.

Summing up the aforementioned research results, it can be concluded that the surveyed employees assessed the company at a low or medium level of advancement of the development of the area of quality management in the supply chain. While differentiating the area of quality management and the area of supply chain management, the former one was confirmed by a significantly smaller group of the respondents. Only $54 \%$ of those questioned showed the knowledge of quality assurance systems and an even smaller group, since amounting to $44 \%$ of all the respondents, pointed out instruments of quality management in the surveyed company. The confirmation of the implementation of the processes of the Quality Manual and their coexistence and convergence with processes of the supply chain was obtained from a very small group of the respondents, since only $24 \%$ of mainly the senior management level. On the other hand, the confirmation of the use of instruments of supply chain management was already higher, since indicated by $74 \%$ of the respondents. At the same time, fairly high awareness of the position of the 
entity in the supply chain and the complexity of its architecture indicated the significant involvement of efforts in the operating activities of the entity.

The connectivity of the areas of quality management and supply chain management, pointed out mainly in intentions to show the impact of quality management and supply chain management on the efficiency of supply chain management was indicated to a minimal extent. Admittedly, the knowledge of the three ways of measurement of the efficiency of supply chain management was confirmed but only one related to the area of quality.

The areas considered were the section of general organizational competences and standards of the business strategy of the company, the knowledge of which among the respondents was much more advantageous.

\section{REFERENCES}

Biesok, G., 2013. Zarządzanie jakością w logistyce, Wydawnictwo Naukowe Akademii Techniczno-Humanistycznej w Bielsku-Białej, Bielsko-Biała.

Czajkowska, A., Stasiak-Betlejewska, R., 2015. Quality Management Tools Applying in the Strategy of Logistics Services Quality Improvement, Serbian Journal of Management, 10(2), 225-234.

Detyna, B., 2015. Zarządzanie jakością logistyce, Wydawnictwo Państwowej Wyższej Szkoły Zawodowej im. Angelusa Silesiusa, Wałbrzych 2015.

Frąś, J., 2013. Kompleksowe zarządzanie jakością w logistyce, Wyższa Szkoła Logistyki w Poznaniu, Poznań.

Hu, H., Flynn, B., Zhao, X., 2014. Global Supply Chain Quality Management: Product Recalls and Their Impact, CRC Press, Boca Raton.

Kadłubek, M., 2018. The essence of quality in corporate logistics management,

Scientific Quarterly Organization and Management, 3(43),17-30.

Kardas, E., Kowacki, W., Czaja, G., 2011. Znaczenie logistyki w zarządzaniu jakością, Logistyka 5, CD.

Lin, C., Kuei, C. H., Chai, K. W., 2013. Identifying critical enablers and pathways to high performance supply chain quality management, International Journal of Operations \& Production Management, 33(3), 347-370.

Łunarski, J., 2012. Zarządzanie jakością w logistyce, Oficyna Wyd. Politechniki Rzeszowskiej, Rzeszów.

Perona, M., Miragliotta, G., 2004. Complexity management and supply chain performance assessment. A field study and a conceptual framework, International Journal of Production Economics, 90(1), 103-115.

Robinson, C. J., Malhotra, M. K., 2005. Defining the concept of supply chain quality management and its relevance to academic and industrial practice, International Journal of Production Economics, 96(3), 315-337.

Sharma, A., Garg, D., Agarwal, A., 2012. Quality Management in Supply Chains: The Literature Review, International Journal for Quality Research, 6(3), 193-206.

Ulewicz, R., Ingaldi, M., Klimecka-Tatar, D., Knop, K., Krynke, M., Mazur, M., Mielczarek, K., Rosak-Szyrocka, J., 2018. Narzędzia jakości w praktyce. Poradnik dla biznesu, Oficyna Wydawnicza Stowarzyszenia Menedżerów Jakości i Produkcji, Częstochowa. 